\title{
Energy (In)Dependence and National Security of Lithuania
}

\begin{abstract}
This article analyses the status of the energy (in)dependence of Lithuania, as well as the effects it may have on the national security. The legacy of the soviet era in Lithuania is an energy infrastructure that conditions absolute dependence of certain energy sectors upon the imports of energy resources from Russia. The article argues that ambitions of Russia are not limited to just this kind of structural influence: Russia is making efforts to strengthen its position in the energy sector of Lithuania even more, by acting all in one with the largest energy companies of its own country, as well as through mediators and/or other means. The use of economic leverages for political ends is an exceptionally firm line in the current foreign policy of Russia, which is also translated into practice of international relations. In the light of the above, expanding influence of Russia in the Lithuanian energy sector prompts negative assessment of the energy independence and national security prospects in future.
\end{abstract}

\section{Introduction}

In its narrow meaning, the energy independence of a country is defined as independence from the imports of energy resources (i.e. possession of its own resources) or at least a possibility to choose from several suppliers. Like many other postcommunist countries, Lithuania succeeded to the energy infrastructure that determines the absolute dependence upon the imports of natural gas, oil, nuclear fuel and other energy resources from Russia. Natural gas from Russia is carried to Lithuania through the single gas pipe Minsk-Vilnius. Mažeikių Nafta oil refinery theoretically could import crude oil through Būtingè Terminal from sources other than Russian oil suppliers; alas, for economic reasons it is also "pegged" to the single pipeline Novopolock-Biržai-Mažeikiai and Russian oil supplies. Ignalina Nuclear Power Plant (NPP), which will remain the main electricity producer in the country until the date fixed for its closure, may import nuclear fuel only from Russia, all due to the specifics of the soviet RBMK type reactors that are used at Ignalina $\mathrm{NPP}^{1}$. The dependence of the Lithuanian energy system upon imports of energy materials from Russia will persist even after the closure of Ignalina NPP: to comply with the stringent environ-

* Živile Šatūnienè - Ph.D. candidate of the Institute of International Relations and Political Science of the University of Vilnius. Address:. Vokiečiu 10, LT-1130 Vilnius, tel.: +370 -5- 25141 30,e-mail: zivileb@yahoo.com

${ }^{1}$ ELTA, Išvengusi muito branduolinio kuro kasetems Lietuva kitamet sutaupys 6,6 mln. litu [Avoiding to Pay Customs Tariff for Nuclear Fuel Cassettes Lithuania Will Save 6.6 Million Litas], 2307 2003 (in Lithuanian). 
mental requirements of the EU, the remaining major power plants will be forced to use natural gas for electricity production, while the existing infrastructure, as already mentioned, allows importing gas from Russia only.

Knowing the importance of uninterrupted supplies of energy resources to the health of the national economy, to industry's competitiveness on the world market, to social and even political stability of the country, the issue of energy independence could be viewed as an issue of national security. In case of Lithuania, where energy resources can physically be imported from Russia only, it does not take a thorough analysis to be able to conclude that the country is economically insecure or insecure in general, should economic security be considered a part of the national security.

This article does not attempt to either prove or deny such conclusion. This article concentrates on the dynamics of the energy (in)dependence of Lithuania, and analysis of the energy security outlook of the country. Like any other country, Lithuania seeks to diversify the sources of energy resources supplies; to balance the interests of the Eastern and Western capital through privatization of major energy companies, and to implement other means designed to strengthen the energy security of the country. This approach is provided for in the main legislation concerning the national security and energy sector development outlook, such as the RL Law No. VIII-49 on the Basics of National Security (19 December 1996); the National Energy Strategy approved by the Resolution No. IX-1130 of the Lithuanian Parliament (10 October 2002); etc. The main objective of this article is to analyze and identify possibilities for strengthening the energy independence of the country; or, in other words, the opportunities for reducing the Russian influence upon the energy sector in Lithuania. To achieve this objective, it is first of all necessary to understand what interests Russia has in Lithuania's energy sector; to analyze the ways and means of their materialization; to identify whether the structural dependence of energy systems of post-communist countries is serving the interests of Russia, and whether there are any attempts of additional and conscious manipulation with such dependence in order to advance wider interests, such as political influence in domestic matters of another country; foreign policy concessions, strengthening dependence on Russia by further impediments to diversification of energy resources in future, etc. One of the best known representatives of (neo)realism in international relations theory Barry Buzan claims that, "the worst case scenario" for the economic security of a country is not when that country is structurally dependent on the supplies of resources, but when the supplying countries attempt to use the resulting vulnerability for gaining favourable political concessions ${ }^{2}$. Thus, one must first analyze interests and behaviour of a supplying country in order to assess the implications of energy dependence for the national security of Lithuania; such analysis is presented in the first part of this article. The second part deals with the influence of Russia in each of the three energy sub sectors of Lithuania (natural gas, oil, electricity), and the likelihood of its expansion or constriction. For this purpose, description of each sub sector is followed by the assessment of the structural dependence on Russia; possibilities or

${ }^{2}$ Buzan B., Žmonés, valstybès ir baimé: Tarptautinio saugumo studijos po Šaltojo karo [People, States and Fear: An Agenda for International Security Studies in the Post-Cold War Era], Vilnius: Eugrimas, 1997, p. 175 (in Lithuanian). 
projects aiming to increase sector's independence from Russia, and "counter actions" by Russia, seeking to sustain or even strengthen its influence in different parts of the Lithuanian energy sector. The article is concluded with the energy (in)dependence and economic security projections for Lithuania.

\section{Russian Energy and Foreign Policy: Interests and Means of Realization}

Representatives of the political science and media almost unanimously recognize the period 1997-2000 was a turning point in Russia's foreign policy, in particular in respect of the Baltic States ${ }^{3}$. Until 1997-1998, the dominating features of the Russian foreign policy were geo-political thinking and point-blank vein: active opposition to the NATO enlargement into the Baltic States, the threat of military actions in response to the violation of its national interests or failure to respect the rights of the Russian-speaking population in the Baltic States, etc. ${ }^{4}$ Subsequently, in particular after the economic crisis in Russia in 1998, the foreign policy tone started changing. Still in 1997 the Russian President signed a document on the Russian long-time strategy in respect of the Baltic States, which aimed at "maintaining potentially friendly relations between Russia and the Baltic States, and developing a model of constructive relations" . Although still objecting to the membership of the Baltic States in NATO, Russia for the first time demonstrated its commitment to pursue subtler foreign policy in respect of the Baltic States, putting more emphasis on the economic levers. The shift from geo-political towards geo-economic reasoning is in particular manifest in the Foreign Policy Concept of the Russian Federation adopted in June $2000^{6}$. The said Concept, which was signed by President Vladimir Putin and is valid to this day, expresses a great interest of Russia in the EU enlargement process, as well as in such issues as transit, investments and accessibility of markets. Interpreting implications of such aspirations for the Baltic States allows presuming, that Russia is interested in ensuring favourable conditions for Russian companies operating in the region, and support to the Russian capital in the strategically important industries of the Baltic States (energy, transit and other sectors). The Concept says that, "seeking to protect its national interests, Russia must be ready to use all the available econo-

\footnotetext{
${ }^{3}$ Godzimirski J. M., "Russian National Security Concepts 1997 and 2000: A Comparative Analysis", European Security 9(4), 2000, p. 73-91; Jensen D. N., "Working with Russians", EBSCO Publishing, 2003; Spruds A., "Political Priorities and Economic Interests in Russian-Latvian Relations", NUPI [620] Working Paper December 2001, p. 1-14, http://www.nupi.no/PubFelles/Notat/ PDF2001/NUPIwp620.pdf, 2006 2003; Blank S. J., "Russia and the Baltics in the Age of NATO Enlargement", Parameters: US Army War College 28(3), 1998, p. 50-69.

${ }^{4}$ For instance, the Military Doctrine of Russia (approved in November 1993) contained a statement, that Russia reserves the right to use military force in the event the rights of Russian citizens are breached in any foreign state, or in case of an attempted assault on forward deployed Russian military bases; or in case of expansion of military blocks posing threat to the Russian security interests. For more details see Spruds (note 3), p. 2.

${ }^{5}$ Ibid., p. 3.

${ }^{6}$ Godzimirski (note 3), p. 73-91.
} 
mic leverages and resources" ". Meanwhile Lithuania, like other post-communist states, traditionally is falling within zone of key interests of Russia, where it wants to retain the influence it once had. Knowing that Russia today has engaged itself into economybased foreign policy, increased influence of the Russian companies in the Lithuanian energy sector could be viewed as part of the formal foreign policy of Russia.

Traditionally the largest Russian energy companies (even without the dominant state capital) act as key partners of the Russian Government in the process of implementing its foreign policy in the post-communist countries. Oil and gas interest groups are among the most influential factors in the development and implementation of both the domestic and foreign policy in Russia ${ }^{8}$. Moreover, the Russian Government and the Russian energy companies have but the same interests in the Baltic States (including Lithuania) which add to the efficiency of the Russian foreign policy whereby it strives to maintain and/or expand its influence in the energy sector of Lithuania.

Russian oil and gas businesses are primarily interested in maximizing their profits. The prices of raw materials in the Russian market being almost half the world market price and purchasing power relatively low, the Russian oil and gas companies are proactively seeking to increase the exports of raw materials into the sound Western markets. For instance, in 1998 Gazprom's revenue in cash amounted to $15 \%$ of the total amount due for natural gas supplies in the domestic market; almost $40 \%$ of gas sold in the domestic market (mainly to the state enterprises and power plants) has not been paid for at all ${ }^{9}$. Average oil sales prices amounted to only $42 \%$ of the international oil price during the first 6 months of 2001 in Russia. International institutions, however, treated this as a "considerable progress", for at the end of 1999 the difference between oil prices in Russia's domestic and on the world markets was expressed by ratio 7:2510. On the other hand Lithuania, although still buying, e.g. natural gas for prices lower than the West European economies, has had not debts to Gazprom since 1997. The solvency of the Baltic States, as well as their geographical proximity to Western Europe impel Russian oil and gas businesses to retain their raw material markets in those countries. Moreover, Lithuanian, Latvian and Estonian markets are soon to join the EU single market, and Russian analysts, as well as oil and gas companies, view them as "support markets" or "training base", which will come handy when Russia will start expanding its influence further into the West ${ }^{11}$. To

\footnotetext{
${ }^{7}$ Концепция внешней политики Российской Федерации, утверждена Президентом Российской Федерации В. В. Путиным 28 июня 2000 г. [Foreign Policy Concept of the Russian Federation Approved by the President of the Russian Federation V. V. Putin on 28 June 2000], http:// www.ln.mid.ru/nsosndoc.nsf/0e9272befa34209743256c630042d1aa/ fd86620b371b0cf7432569fb004872a7? OpenDocument, 15072003 (in Russian).

${ }^{8}$ For more information see also Jaffe A. M., Manning R. A., „Russia, Energy and the West“, Survival 43(2), 2001, p. 133-136; Khripunov I., Matthews M. M., „Russia's Oil and Gas Interest Group and Its Foreign Policy Agenda“, Problems of Post-Communism 43(3), 1996, p. 38-40; Adams J. S., „Russia's Gas Diplomacy“, Problems of Post-Communism 49(3), 2002, p. 14-15; etc. ${ }^{9}$ International Energy Agency, Russia Energy Survey 2002, OECD/IAE, 2002, p. 39-40.

${ }^{10} \mathrm{Ibid}$, p. 76.

${ }^{11}$ Зарубежная экспансия российских нефетегазовых компаний: итоги и перспективы. Аналитический доклад [Foreign Expansion of the Russian Oil and Gas Companies: Results and Prospects. Analytic Report], Москва: Центр политической конъюнктуры России, 2002, p. 3-4, http://www.ancentr.ru, 15 052003 (in Russian).
} 
maximize their profits, Russia's oil and gas companies are eager to control the entire chain, from production to the end user sales; consequently, they are interested in holding oil processing, natural gas transportation and supplies, electricity generation and transmission, as well as energy resources and energy export capacities in Lithuania and in other post-communist countries. The business experience from Lithuania, especially in the view of its prospects of becoming a full-fledged member of the EU, would be an asset for Russian energy companies in their efforts of implementing their long-term strategies of expanding into the West.

Expansion of energy companies westwards is also a matter of "national security level" for the Russian Government. First and foremost, revenues from energy resources export account for more than $20 \%$ of GDP and approximately $50-60 \%$ of the foreign currency income in Russia ${ }^{12}$. Taxes paid to the state budget by oil sector companies alone make $25 \%$ of the tax base ${ }^{13}$. After considerable decline of the world oil prices in 1998, the exports revenue of Russian oil companies decreased by some $30 \%$, and economy of the country was hit by crisis. Thus, the Russian Government is forced to support expansion of the energy companies into the West in order to ensure social and economic stability in the domestic arena. In May 2003, the Government of the Russian Federation approved the National Energy Strategy until 2020, whereby it granted political support for activities of the Russian oil and gas companies in the export markets seeking to gain the maximum benefits from transit and export of energy resources, and to acquire additional processing and export capacities (including power plants) $)^{14}$.

The approach of the Russian Government, albeit informal, is that the expansion of its energy companies into foreign countries (e.g., the Baltic States) should be encouraged for political reasons, too. In several reports Russian analytic centers and NGOs acting in the capacity of advisers to the Government emphasized that expansion of the Russian energy companies in the Baltic States provides Russia's Government with an opportunity to influence political decision-making processes of the energy-dependent countries; and that the Government, therefore, should improve this opportunity more actively ${ }^{15}$. Analytic NGOs report that executive authorities in Russia support expansion of oil and gas companies into the Western markets. In the meetings with managers of the major oil companies, President of the Russian Federation Putin has repeatedly underlined the necessity of strengthening Russia's business positions abroad ${ }^{16}$. The pressure upon decisions of the political elite of the energydependent countries may be expressed not only by drastic means, such suspended oil

${ }_{12}$ Jaffe (note 8), p. 134.

${ }^{13}$ Ibid.

14 Энергетическая стратегия России на период до 2020 года [National Energy Strategy of the Russian Federation until 2020], http://www.mte.gov.ru/files/103/876.strategy.pdf, 29072003 (in Russian).

${ }^{15}$ For instance, refer to the proposals for the Russian Government developed by the Russian NGO National Foreign Policy laboratory, concerning a more efficient protection of the national interests in Latvia: Латвия: политические действия, местная экономика и российские интересы [Latvia: Policy Actions, National Economy and Russian Interests], http://www.nlvp.ru/reports/61.html, 20072003 (in Russian); or the Report on Foreign Expansion, drafted by NGO Centre of Russian Political Conjuncture, the clientele whereof includes Russian ministries, special services and other authorities: Зарубежная экспансия, (note 11) p. 3-4.

${ }^{16}$ Ibid., p. 3, 6. 
or gas supplies, but also resorting to a much more subtle ways like raising the price on raw material exports. Increased prices for energy resources immediately cause increase of the consumer price levels, which may, in its turn, provoke inflation, social instability, discontent with the existing government and a change in the deployment of political powers rendering, perhaps, a more favourable attitude in respect of Russia. Alternatively, seeking to evade the above scenario the existing government would be impelled to make political decisions that favour Russia. Thus, there is no doubt that Russia is interested in preserving the presence of its companies in the energy sector of Lithuania, for it represents a powerful instrument of political leverage.

Another, not the least important reason justifying support of the Russian Government for the extended presence of its energy companies in the Baltic States is the future membership of these countries in NATO. NATO enlargement is useful for Russia: once the energy-dependent countries join NATO, Russia will gain additional opportunities to influence consensus based decision-making in the Alliance, as well as to reinforce its position in respect of NATO and USA. For instance, a report by the Centre of Russian Political Conjuncture argues "if Russians control business in the Baltic States, the political elite of these countries will find it complicated to openly manifest a position that is unacceptable to Russia, whether or not these countries become members of the EU and NATO"17.

Thus dependency of Lithuania and other Baltic State upon imports of energy resources from Russia poses a real threat not only to the physical base (economy), but also to the political independence of these countries. The threat is intensified by Russia's attempts to manipulate with energy dependency of other countries for political purposes in the past. In other words, the threat for the national security resulting from the energy dependency is a "historical concern" (according to Buzan, historical concern is one of the criteria that determine intensity of a threat ${ }^{18}$ ).

For instance, shortly after Poland joined NATO, Gazprom started selling natural gas for the country at world level prices, which determined the decline of the living standard in Poland and undermined its competitiveness on the world markets $^{19}$. There are also examples to the opposite: the victory of the pro-Russian Communist party in the elections in Moldova in 2001 was promptly followed by an agreement with Gazprom to cut prices for natural gas, write-off the gas fines that accumulated since 1994, an arrangement of paying for gas by barter, etc. ${ }^{20}$ In 2002 Latvia was also subjected to economic and political pressure by Russia: Russia was gradually reducing the quantities of oil transhipped at Ventspils oil terminal for transit into other countries, and suspended all its activity at Ventspils terminal during the first three months of 2003. Analysts estimated that the decline in transit and terminal loading activity resulted in a reduction of the Latvian GDP by 0.5 percent in $2002^{21}$. Although the official line was that Russia had chosen other oil terminals on the shore

${ }^{17}$ Ibid.

${ }^{18}$ Buzan (note 2), p. 187-189.

19 Зарубежная экспансия (note 11), p. 49.

${ }^{20}$ Moldova Premier Pleased with Talks with Russian Gazprom Chief, http://english.pravda.ru/comp/ 2001/08/09/12099.html, 29072003.

21 Латвия: политические действия (note 15$)$. 
of the Baltic Sea for more favourable transit fees, many analysts agreed the main reason for such a blockade being the pressure upon the Latvian government to sell shares of Ventspils Nafta to the interested Russian companies (all the more so as the blockade of the oil terminal by Russia was not withdrawn when exceptionally good rates for Russian oil transit through Ventspils were fixed ${ }^{22}$. Lithuania was in a similar situation during the process of privatising $\mathrm{AB}$ Mažeikių Nafta. After unsuccessful attempt to become an operator of AB Mažeikių Nafta, Lukoil was actively exercising its powers as a coordinator of Russian oil supplies throughout 1999-2000. The US company Williams International, the operator of AB Mažeikiu Nafta oil refinery, was practically not allowed to reach any agreement with other Russian oil companies regarding raw material supplies, while Luikol's prices for oil were artificially raised. The Russian media was reporting that Lukoil was exercising the commercial blockade of Mažeikiu Nafta under the auspices of the Russian Ministry of Fuel and Energy, seeking to compromise and eliminate the American capital (Williams International) from Mažeikiai oil refinery ${ }^{23}$.

In the light of the above, the following conclusions could be made:

1.Economic levers are becoming an important weapon of Russia's foreign policy arsenal.

2.Russian energy companies and the Russian Government have the same interests in the post-communist countries (including Lithuania), thus the Government of Russia manifests active support to consolidation of their presence in the strategic sectors of the dependent countries.

3.The Russian Government is interested in retaining and strengthening its influence on the energy sector of the dependent countries as long as possible. 4.Energy dependence of the Baltic States (including Lithuania) on imports of energy resources from Russia is a realistic threat not only to economic security, but also to political independence of these countries. The threat is intensified by Russia's inclination to manipulate energy dependence for political purposes.

\section{Russia's Interests in the Lithuanian Energy Sectors: Projected Changes in National Security Profile}

\subsection{Natural Gas}

Lithuania uses about 2.7 billion cubic meters of natural gas annually ${ }^{24}$. Natural gas reaches Lithuania from Russia (Gazprom as the prime supplier) through the

\footnotetext{
${ }^{22} \mathrm{Ibid}$.

${ }^{23}$ Правосудов С., ,Мажейкяй, как стратегическая точка Литвы, и три российские компании“ [Mažеikiai as Strategic Object of Lithuania, and Three Russian Companies'], http://www.smi.ru/text/01/07/02/ 111742.html, 20042003 (in Russian); Global Intelligence Update, Russia Slashes Oil Supplies to Lithuania, Red Alert, February 3, 1999, http://www.malaysia.net/lists/sangkancil/1999-02/ msg00013.html, 2004 2003, etc.

${ }^{24} \mathrm{AB}$ "Lietuvos dujos", Bendras gamtiniu duju naudojimas Lietuvoje [Aggregated Use of Natural Gas in Lithuania], http://www.dujos.lt/lt43.html, 02082003 (in Lithuanian).
} 
territory of Belarus by a sole gas pipeline Minsk - Vilnius. The gas supply infrastructure inherited by Lithuania from the Soviet era, provides no possibility to import natural gas from sources other than Russia ${ }^{25}$. It is often argued that reliability of gas supplies to Lithuania is increased by the fact that the territory of Lithuania is used to supply gas to the Kaliningrad area of the Russian Federation, which also has no possibility to get gas from elsewhere. Taking into account the negligent size of the Lithuanian gas consumer market (in 2002 Gazprom extracted approximately 522 billion $\mathrm{m}^{3}$ natural gas ${ }^{26}$, and the share of sales to Lithuania accounted only for 0.5 percent of this amount), it is nevertheless hard to expect that Lithuania's control over the gas transit to Kaliningrad region could be a strong argument in negotiations with Gazprom over more favourable prices for gas and terms of supply.

In general, the natural gas sub sector is of exceptional importance to the energy system of Lithuania: gas supplies and prices are critical for uninterrupted operation of certain industries (fertilisers, glass or other product manufacturers), as well as determine the prices for heating and electricity (majority of the power plants, except for Ignalina NPP, prefer using more environment-friendly gas to fuel oil; on the other hand, they are forced to do so in order to comply with strict environmental standards and avoid high pollution taxes), etc. Should the prices for this resource increase, it may destabilise the social situation (e.g., increased charges for utility services and prices for consumer goods may cause a strong reaction from the low income groups of population), cause inflation, undermine international competitiveness of the country, etc. Thus Russia, being in control over Lithuania's natural gas sector, has an exceptionally powerful instrument to influence the political life of the country, including decision-making processes and distribution of the governing political powers. Moreover, once Ignalina NPP is closed, natural gas will be the main fuel used for production of electricity ${ }^{27}$, therefore the threat for national economic security posed by the dependence on natural gas is bound to increase, too.

For the purpose of analyzing realization of the Russian interests in the Lithuanian energy sector, it is important to remember, that Gazprom, a company holding world-largest reserves of natural gas and pipeline system, is also the most consistent executor of the official Russian foreign policy provisions..$^{28}$ The controlling interest is

${ }^{25}$ AB "Lietuvos dujos", Lietuvos gamtiniu duju tiekimo sistema [Natural Gas Supply System of Lithuania], http://www.dujos.lt/lt41.html, 02082003 (in Lithuanian). Apart from the connection Minsk - Vilnius, in the Lithuanian natural gas supply system there are other points connecting cross-border gas supply pipelines: Ivacevici (Belarus) - Vilnius and Riga (Latvia) - Panevezys. Gas supply branch Ivacevici - Vilnius stands idle. This segment could introduce some changes in the transit route of the Russian natural gas through the territory of Belarus in case, for instance, of a technical accident on the route Minsk - Vilnius; however, these changes will not have any impact on the dependency of Lithuania upon natural gas imports from Russia. Theoretically connection Riga - Panevezys could enable exporting natural gas from Latvia, but the latter has no resources of its own, being dependent on the natural gas imports from Russia, too. Thus, the existing cross-border connections of Lithuania and neighbouring countries do not add to the energy independence of this country.

${ }^{26} \mathrm{OAO}$ «Газпром», Основные итоги деятельности ОАО «Газпром» за 2002 год [Main Outcomes of Gazprom Activity in 2002], http:/www.gazprom.ru/articles/article4861.shtml, 03082003 (in Russian).

${ }^{27}$ Simėnas D., „Lietuva be Ignalinos vartos keliskart daugiau dujų“ [,Gas Consumption Will Triple After Closure of Ignalina NPP'], Verslo žinios, 16112001 (in Lithuanian).

28 Зарубежная экспансия, (note 11), p. 6, 49-52; Khripunov (note 8), p. 38-40 etc. 
held by the State together with the company; as a rule, the top managers of the company were always people close to the regime. For instance, when President of the Russian Federation was Boris Yeltsin, Gazprom was managed by V.Chernomyrdin, the former Minister of Fuel and Energy; he was succeeded by R.Viakhirev, the former Deputy Minister of Fuel and Energy ${ }^{29}$; in 2000, when Putin was elected President of the Russian Federation, management of Gazprom was entrusted to A.Miller, an emigrant from St. Petersburg, who knew personally and was close to the President ${ }^{30}$.

In its National Strategy, Lithuania has committed to diversification of the sources of natural gas supply. Despite the existing international projects aiming at exploration of possibilities to provide Poland, Lithuania and maybe some other countries of the Eastern Europe with natural gas extracted by Norway or Denmark in the North Sea ${ }^{31}$, Lithuania's possibilities to evade complete dependence from Russian gas remain highly unassured both for the objective reasons that are beyond Russia's control, and because of active attempts by Gazprom to gain control over the Lithuanian sector of natural gas by preventing any possibility of implementing Lithuanian gas supply system development projects that are detrimental to Russia's interests.

The group of "objective" reasons preventing Lithuania from achieving independence in the sector of natural gas, includes the following circumstances:

1. At present, there is a huge difference between the price for gas paid to Gazprom by Lithuania and the market price for gas, which is usually defined as an average price for gas exported by Russia/Norway into the Western Europe ${ }^{32}$. Once Lithuania completes liberalization of the natural gas sales market as required by the EU, consumers will have a freedom of choice, and there might be no demand for Norwegian gas. Knowing this, private investors are not likely (at least in the near future) to be interested in building a pipeline to provide Lithuania with natural gas from Norway. 2. Based on different calculations, the explored natural gas reserves in the North Sea will suffice only for some 25 years ${ }^{33}$.

3. Theoretically, Lithuania could import natural gas from the Western countries, provided the feasibility of implementing such project will be

\footnotetext{
${ }^{29}$ Ibid.

${ }^{30}$ Незаменимых нет [Everyone Can Be Replaced], http://www.garweb.ru/project/vas/news/smi/01/05/ 20010531/317952.htm, 09082003 (in Russian); Алексей Миллер сменил Рема Вяхирева на посту председателя “Газпрома" [Alexey Miller Replaced Rem Viachirev at Gazprom], http://www.garweb.ru/ project/vas/news/smi/01/05/20010530/317267.htm, 09082003 (in Russian), etc.

${ }^{31}$ Sytas A., „Dujos į Baltijos šalis tekès per Lietuvą“ [,Gas to Other Baltic States Will be Transported Through Lithuania'], Verslo žinios, 23072001 (in Lithuanian).

${ }^{32}$ For instance, in 2001 the average price for gas for the Western European countries was 136 USD / $1000 \mathrm{~m}^{3}$, while Lithuanian companies bought natural gas from Gazprom at 77-79 USD / $1000 \mathrm{~m}^{3}$. For more details, refer to International Energy Agency (Footnote 8), p. 127; as well as Damauskas Ž., „Dujų kainą lems įmonès privatizavimo scenarijus“ [,Privatisation Scenario Will Determine Gas Prices'], Lietuvos rytas, 20010924 (in Lithuanian). For instance, in 2001 Poland was buying gas from Gazprom for an average price of $122 \mathrm{USD} / 1000 \mathrm{~m} 3$, while the price for Norwegian gas would be about 150 USD / $1000 \mathrm{~m} 3$. For more detail, ibid.

${ }_{33}$ The European Union Energy Policy, http://www.emu.edu.tr/ eefegil/europeanunion.htm, 0908 2003.
} 
agreed in advance by Norway, Denmark, Poland and other Eastern Europe countries which could undertake to consume a certain amount of Norwegian gas (as estimated by Norwegians, building of a pipeline is feasible only if Poland consumes annually at least 8 billion $\mathrm{m}^{3}$ of gas from the North Sea; however Poland has already signed a long-term gas supply contract with Gazprom, which will completely meet the growing consumption needs of the country at least for ten years) ${ }^{34}$.

Under these circumstances it clearly will not be easy for Lithuania to diversify its natural gas supply sources. Even if other above mentioned countries were working hand in hand, such project would not be of commercial nature, and the state would have to make certain budget allocations (the value of the projects amounts to approximately 11 billion $\mathrm{USD}^{35}$ ). Taking into account the fact that development and implementation of the alternative gas supply projects could provoke discontent of the present sole gas supplier Gazprom, and increase of the prices for natural gas for Lithuanian consumers, there is little hope that any government of Lithuania would dare to initiate these processes.

Gazprom is eagerly striving to control the natural gas sales market in Lithuania, thus gaining additional chances to keep Lithuania dependent only from Russian gas supplies.

Like in other countries that depend from Russia "energy wise", in Lithuania Gazprom resorts to two instruments of ensuring its influence: 1) by participating in privatisation of gas companies which administer the pipeline infrastructure and sell natural gas to the end users in the dependent countries; and 2) by establishing its mediating companies in the dependent markets.

When privatising AB Lietuvos Dujos (Lithuanian Gas Company), the Lithuanian government decided to seek for a fair balance between the Eastern and Western interests: an investor meeting the criteria of "European and transatlantic integration", and a natural gas supplier were to be offered to acquire equal shares of $\mathrm{AB}$ Lietuvos Dujos, i.e. $34 \% \mathrm{each}^{36}$. The first block of shares was sold to the German consortia of Rurhgas and E.on. companies. Negotiations with the supplier - Russian Gazprom - took longer than expected, and the privatisation process is not over yet to this day ${ }^{37}$. Lithuania's negotiation position is weakened by unsuccessful experience of privatising AB Mažeikių Nafta, when appointment of the Western company to operate oil refinery Mažeikiu Nafta prompted Russia to take up actions against Lithuania and suspend supplies of oil to the refinery at market prices. Another detri-

\footnotetext{
${ }^{34}$ ELTA, Norvegija ragina Rytu Europa ir Baltija išgelbetti duju plana [Norway Calls upon the Eastern Europe and the Baltics to Save the Gas Plan], 06062002 (in Lithuanian).

${ }^{35}$ Ibid.

${ }^{36}$ See 4 October 2001 Resolution No.1194 of the Lithuanian Government "Dèl LRV 2000 m. kovo 2 d. nutarimo Nr. 246 "Dèl AB "Lietuvos dujos" pagrindinių privatizavimo bei pertvarkymo nuostatu patvirtinimo" dalinio pakeitimo" [,Amendment of the 2 March 2000 Government's Resolution No. 246 re. Approval of the Principle Privatisation Provisions and Restructuring Regulations regarding $\mathrm{AB}$ Lietuvos Dujos'] (in Lithuanian).

${ }^{37}$ As for September 2003
} 
mental factor is that Gazprom is the only company qualifying for the second $34 \%$ block of AB Lietuvos Dujos shares. Thus, it is highly probable that namely Gazprom will become the co-owner of the Lithuanian gas company.

On the other hand, Gazprom would still be able to control completely the Lithuanian gas sales market in its capacity of sole gas supplier, without making its way into the management of the Lithuanian gas company. If necessary, Gazprom could injure the Lithuanian counterpart economically. To ensure its influence, Gazprom has established own mediating companies in almost all former Soviet and postcommunist countries of the Eastern Europe. Until 1992, natural gas in Lithuania was bought directly from Gazprom and sold to consumers by the Lithuanian gas company only. Gradually other gas suppliers emerged in the market, and started selling gas either to the Lithuanian gas company or to the major end users directly. The share of gas bought by the Lithuanian gas company was continuously falling, while mediating companies were getting the largest shares of the market and the most favourable prices of natural gas. From 2002 the market has been dominated by Dujotekana, Gazprom's mediator. In 2002 the value of AB Lietuvos Dujos direct sales was only 0.58 billion $\mathrm{m}^{3}$ of natural gas, which made some $22 \%$ of natural gas consumed in Lithuania annually ${ }^{38}$.

As a rule, Gazprom offers to a selected mediating company not only the largest gas quota, but also a price which is lower than that offered to other operators ${ }^{39}$. Such policy allows the Russian gas corporation to have an absolute control over the natural gas market in a dependent country. There might be several gas providers in a market (in case of Lithuania there are two: private company Dujotekana and Lietuvos Dujos), but they do not compete in reality, as there is only one prime gas supplier: a mediating company loyal to Gazprom resells gas at lower prices to the major gas consumers, thus holding the largest share of the market, while the national company, which holds all the gas supply networks and thus experiences higher operational costs, purchases natural gas from Gazprom at higher prices and holds only a negligible share of the market. Moreover, such policy may have a negative reflection on the financial indicators of the "unprivileged" company; and if such company is listed for privatisation, which is the case with Lietuvos Dujos, Gazprom has a possibility to push the price for the company downwards.

The fact that over 50\% of Gazprom's shares are owned by the State and the company itself, leads to a presumption that control of the natural gas market though mediators in Lithuania, like in many other dependent countries, makes a part of the state policy line of Russia. This could be evidenced by the fact that at the end of 2001 President V.Putin has publicly demanded Gazprom to give up the practice of selling gas through mediators abroad, since Gazprom and, consequently, the Russian budget was loosing a considerable amount of potential income ${ }^{40}$; however at the beginning

\footnotetext{
${ }_{38} \mathrm{AB}$ "Lietuvos dujos", Liberalizuota prekyba gamtinemis dujomis [Natural Gas Trade Liberalisation], http://www.dujos.lt/lt42.html, 09082003 (in Lithuanian).

${ }^{39}$ Kulikauskas T., „Rusija padidins gamtinių dujų kainą Lietuvai“ [,Russia to Increase Gas Prices for Lithuania'], Respublika, 29052003 (in Lithuanian); Damauskas Ž., "Gazprom” nori padidinti duju kainas Lietuvai“" [,Gazprom Wishes to Increase Prices for Lithuania'], Lietuvos rytas, 1311 2002 (in Lithuanian), etc.

40 Путин - “Газпрому”: зачем отдаете так дешево? [Putin to Gazprom: Why Sell So Cheap?], http:// lenta.ru/russia/2001/11/20/urengoi/, 26052003 (in Russian).
} 
of the year 2002 Lithuanian natural gas market already had a new player - Gazprom's mediator private company Dujotekana. Knowing the loyalty of the Russian gas corporation to the regime, one may presume that the benefits of having mediating companies in Lithuania are greater than losses to the national budget of Russia, which could be easily avoided if Gazprom could sell gas in the dependent countries without any mediators at all.

Although the Lithuanian natural gas sector is already to a large extent structurally dependent upon the natural gas imports from Russia, the latter, nevertheless, makes effort to ensure its long-term influence in the sector. Gazprom's mediating companies are serving as tools for control over the natural gas sales market in Lithuania. Through its mediating companies, Gazprom may also impinge on the value of the to-be-privatised Lietuvos Dujos. Established role of Russia's gas corporation in this company will enable Russia to block unacceptable gas sector development projects that Lithuania may have in future (e.g., connection of the national gas supply network with the European one), thus Lithuania's chances to free its natural gas sector from dependence on a sole supplier are nothing less than doubtful.

\subsection{Oil}

In the sixties and eighties of the last century, an integrated oil refinery complex was built in Lithuania. It consisted of oil refinery AB Mažeikių Nafta, Birzai Oil Pumping Facility and the oil main Novopolock (Belarus) - Birzai; from Birzai one arm of the oil main is directed to oil refinery Mažeikių Nafta, and the other to Ventspils. The oil refinery complex was designed to process the oil extracted in Russia, and to supply with oil products the entire Northwest region of the Soviet Union. After Lithuania regained its independence, the oil refinery complex was supplemented with Butinge oil export-import terminal in the Baltic Sea (launched in 1999). The terminal enables Lithuania to import and process oil from sources other than Russia. In reality, however, this is not a viable option, since transportation of oil to Butinge Terminal by oil tankers would be a lot more expensive than carrying oil from Russian oil fields by pipelines, thus making Mažeikiai Oil Refinery products not competitive in the market. Moreover, the design capacity of Mažeikiai Oil Refinery is 15 million tons per year, while Butinge Terminal may import only 6 million tons of oil annually (capacity of the oil main arm to Mažeikiai Oil Refinery amounts to 16 million tons per year $)^{41}$. In 2002, Mažeikiai Oil Refinery processed 6.6 million tons of oil ${ }^{42}$.

Thus, the existing infrastructure allows Lithuania to get crude oil from other regions of the world, although in reality the oil economy of the country still depends upon oil supplies by pipelines from Russia. In fact, Lithuania has some oil resources of its own: the geologically projected and actually extracted oil resources amount correspondingly to 278 million and 87 million tons ${ }^{43}$, but the economic conditions

${ }^{41}$ AB "Mažeikių nafta”, Naftos perdirbimo įmone [Oil Refinery], http://www.nafta.lt/content.php?pid=22, 26052003 (in Lithuanian); AB „Mažeikių nafta“, Vamzdynai [Pipelines], http:/ /www.nafta.lt/content.php?pid=56, 26052003 (in Lithuanian).

${ }^{42}$ AB „Mažeikių nafta“, Visa 2002 metu ataskaita [Complete Activity Report 2002], http://www.nafta.lt/content.php?pid=147, 26052003 (in Lithuanian).

${ }^{43}$ Miškinis A., Galinis A., Kugelevičius J., Lietuvos energetikos dabartis, problemos, perspektyvos [The Present, Future and Problems in the Lithuanian Energy Sector], Kaunas: LEI, 1999, p. 32 (in Lithuanian). 
and the existing infrastructure are not suitable for procession of the Lithuanian oil in Mažeikiai Oil Refinery.

Capacity of Mažeikiai Oil Refinery is exceeding the oil needs of Lithuania by far, but the idle time of Būtinge export terminal, e.g. in years 2000 - 2001, is detrimental both to the company, and to the state budget. Contribution of AB Mažeikiu Nafta to GDP of Lithuania amounts to approximately $10 \%^{44}$; therefore provision of the oil refinery with quantity of crude oil sufficient for its operation and export through Butinge Terminal is of great relevance for the economic stability of Lithuania. In 2002, 6.1 million tons of oil were exported through Būtinge Terminal ${ }^{45}$, its export capacity is 8 million tons annually ${ }^{46}$.

On 19 September 2002 a Russian oil company Yukos purchased from Williams International Company its interest in AB Mažeikių Nafta thus becoming a holder of the controlling interest (53.7\%) in the company. Since then Yukos acquired de facto control over the businesses of oil supply to Lithuania, and oil refinery and export through Butinge Terminal. When Yukos started running AB Mažeikiu Nafta in 2002, the oil refinery was processing exclusively oil from Yukos, and over $50 \%$ of the crude oil exported through Būtinge also belonged to Yukos ${ }^{47}$.

Unlike in the natural gas sector, the dominance of the Russian company Yukos in the oil sector is determined by its formal capacity of a holder of the controlling interest in AB Mažeikių Nafta, as well as by certain Government concessions and business guarantees handed over by Wiliams International, including, for instance, preferential rate for oil handling services at Klaipeda oil terminal (company AB Klaipedos Nafta), and $15 \%$ customs duty on oil products imported into Lithuania ${ }^{48}$. These and other concessions enable Yukos to dominate also in those markets where it has no controlling interested in the operating companies. For instance, approximately one third of oil products retail market is held by the Western companies, such as Statoil, Neste or others; but due to economic reasons, these companies prefer buying oil products from AB Mažeikių Nafta, which is run by Yukos, rather than importing from other Western countries ${ }^{49}$. Lithuania consumes only some $28-30 \%$ of the oil products produced by AB Mažeikių Nafta; the rest is exported to Poland, Latvia, Estonia and other countries ${ }^{50}$, mainly through oil terminal operated by AB Klaipèdos Nafta. AB Mažeikių Nafta is the main client of Klaipeda oil terminal. Seeking to maximise its income and control the entire production chain until the product is sold

\footnotetext{
${ }^{44}$ Wines M., ,„Место Большого брата занимает Большая нефтяная компания?““ [,Big Brother Replaced by big Oil Company?'], The New York Times, 2009 2002, http://www.inosmi.ru/stories/01/07/19/ 3013/158836.html, 26052003 (in Russian).

${ }^{45} \mathrm{AB}$ „Mažeikiu nafta“, (note 41).

${ }^{46} \mathrm{AB}$ „Mažeikiu nafta“, Būtingès terminalas [Butinge Terminal], http://www.nafta.lt/content.php?pid=55, 26052003 (in Lithuanian).

${ }^{47}$ Žr. Beinoravičienė R., "Jukos” vadovai žvalgo pirkinį“ [,Yukos Explores the Purchase“], Lietuvos žinios, 30082002 (in Lithuanian).

${ }^{48}$ ELTA, "Yukos" paprieštaravus, Vyriausybe nesiryžo mažinti muito arktiniam dyzelinui [After Yukos Objection, Government Did Not Dare to Decrease Customs Duty for Arctic Diesel Fuel], 16 012003 (in Lithuanian).

${ }^{49} \mathrm{Ibid}$.

${ }^{50} \mathrm{AB}$ „Mažeikių nafta“ (note 41).
} 
to the end user, Yukos is interested in taking part in the privatisation bid for $\mathrm{AB}$ Klaipeddos Nafta. The RL Law No. IX-1132 on Undertakings and Equipment of Strategic Importance for the National Security Purposes, as well as on other Undertakings of Importance for the Purpose of Ensuring the National Security adopted on 10 October 2002 provides for a condition that the State must retain the determining powers in the company Klaipedos Nafta. Alas, AB Klaipedos Nafta does not contribute to strengthening the economic security of Lithuania or reduction of the Russian influence in the sector even if it is not privatised: due to the existing infrastructure, other clients (apart from Mažeikių Oil Refinery un by Yukos) of the company are also oil product manufacturers or their mediators from the East.

Compared to other Russian oil companies, Yukos is traditionally considered to be less politicised. Management of the company underlines, that they are interested just in doing business in Lithuania, and Yukos is sticking to the principle of staying out of the politics, does not finance any electoral campaigns, etc..$^{51}$ On the other hand, Yukos has not dissociated itself from politics in Russia: after the incidents with law enforcement authorities in July 2003, the management of Yukos declared their commitment to co-operate with the opposition political powers in Rus$\mathrm{sia}^{52}$. Incidentally, President of the Russian Federation had a meeting with the president of Yukos Mikhail Khodorkovsky in person as early as in spring 2002, and, according to the media, encouraged him to concentrate more efforts on the Eastern Europe $^{53}$. Soon after, in June 2002 Yukos became a shareholder of AB Mažeikiu $\mathrm{Nafta}$ and provided the refinery with long-term oil supply and export guarantees. The political nature of Yukos' presence in the Lithuanian market can also be evidence by a fact, that for a long time Lithuania has been in the interest zone of the Russian oil company Lukoil, which has the country largest network of gas stations. Representatives of Lukoil were active in the process of privatising AB Mažeikių Nafta, and later co-ordinating supplies of oil from Lithuania to Latvia. All of the above leads to a conclusion that the decision regarding "division of the interest zones" and Yukos investments into Lithuania must have been made on the higher levels of the Russian authorities ${ }^{54}$.

Like natural gas sub sector, the Lithuanian oil market depends upon crude oil supplies from Russia; and in both sectors Lithuania has some trump cards to keep Russia from imposing drastic measures, such as suspension of supplies. The strong point in the natural gas sector of Lithuania is the transit of natural gas through its territory to Kaliningrad region. In oil sector, Russia has a particular interest in Butinge oil export terminal, since oil extraction by Russian companies is increasing more rapidly than consumption, leaving them with the shortage of oil export capacity.

${ }^{51}$ For instance, statements by Lord Owen, the Chairman of the Board, Yukos International, in Lopeta V., "Jukos" atstovai ragina nebijoti Rusijos" [,Yukos Says Not to be Afraid of Russia"], Lietuvos žinios, 29082002 (in Lithuanian).

${ }^{52}$ „Karas su “Jukos” dar nesiliauja“ [,War with Yukos Continues"], Respublika, 29072003 (in Lithuanian)

53 Зарубежная экспансия, (note 11), p. 42.

${ }^{54}$ Седов Н., Битва при Мажейкяе. ЮКОС обошел ЛУКОЙЛ в Литве, но локальный конфликт вряд ли выльется в затяжную войну гиганто [Battle Over Mažeikiai. Yukos Beats Lukoil in Lithuania, but Local Conflict is Unlikely to Grow Into Long-Lasting Fight of Giants], http://www.rusenergy.com/ investindex/a18062001.htm, 02082003 (in Russian). 
To export oil to the North European countries, such as Finland, Germany, the Netherlands, the UK, Belgium, etc., Russia uses terminals located on the Western coast of the Baltic Sea: Ventspils Terminal in Latvia with annual capacity of 30 million tons; Gdansk Terminal in Poland, Būtinge Terminal in Lithuania (annual capacity 8 million tons; to be increased to $13-14$ million tons per year) ${ }^{55}$. A part of Russian oil is exported through terminals in Estonia, where oil from Russia is brought by railway.

In general, more than half (57\%) of Russian oil is exported through terminals, and only a minor part is carried by oil pipelines. As early as in 2000 the export capacity of oil terminals in the Baltic and Black seas was used by $89 \%$ on average. The oil pipeline Druzhba, which carries Russian oil to the West European countries, also had an idle reserve capacity of $10 \%$ only $^{56}$. According to Russia, out of all oil terminals in the Baltic and Black seas, only Ventspils and Būtingè still have a certain reserve oil export capacity ${ }^{57}$.

On the other hand, an economic pressure of Russia upon Ventspils oil terminal in 2002 demonstrates that the mere existence of export capacity in the country is not a self-contained guarantee of energy supplies. There are also a number of other factors that contribute to weakening Lithuania's position with regard to Russia. At the end of 2001, a brand new oil terminal was built and put into operation in Primorsk near St. Petersburg (project "Baltic Pipeline System"). Although the sea in Primorsk is frozen for 6 months of a year, the current export capacity of the terminal amounts to 12 million tons per year. After building additional arms of the oil pipeline, Russia expects to export up to 50 million tons of oil annually through Primorsk ${ }^{58}$. Russia invested about 550 million USD into this project, and all comments to the feasibility of the project underlined its potential to increase Russia's security by eliminating the imminence of depending upon export through individual foreign countries, and to strengthen Russia's position in negotiations over the port duties for oil carried through the terminals of other Baltic States ${ }^{59}$. According to oil refinery Mažeikių Nafta, in 2002 the company incurred a loss of about 5 million USD of income due to the competition with Primorsk ${ }^{60}$.

To conclude, structurally the oil market of Lithuania is not completely dependent upon crude oil supplies from Russia. However, after Yukos became the holder of the controlling interest in Mažeikių Nafta oil refinery, the economic control over the Lithuanian oil sector is now in the hands of this Russian company. Lithuania is refining only Russian oil, for it is more worthwhile. Moreover, Yukos strives to strengthen its position in those businesses that will enable the company to control the entire chain of production, from manufacturing a product until its sales to the end user; i.e. in Klaipeda oil products export terminal and in retail fuel market. Yukos is

\footnotetext{
$\overline{{ }^{55} \text { International Energy Agency (note 9), }}$ p. 12, 94.

${ }^{56} \mathrm{Ibid}$.

${ }^{57}$ Ibid.

${ }^{58}$ For more details, ibid, p. 97.

${ }_{59}^{5}$ Цели и задачи проекта [Aims and Tasks of the Project], http://www.lenobl.ru/transport1, 0908 2003 (in Russian).

${ }^{60}$ Senapedienė E., „Ventspilis smukdo Mažeikius“ [,Ventspils Sinks Mažeikiai'], Verslo žinios, 0502 2003 (in Lithuanian).
} 
not entirely isolated from politics in Russia, although it neither follows the political will of the present government. Meanwhile, V.Putin's government is committed to reduce Russia's dependency upon oil pipelines in the ports of the Baltic Sea countries: the project "Baltic Pipelines System" has abated economic security of Lithuania, for the export capacity existing in the country is no longer so important for Russia after it has constructed an oil terminal in Primorsk.

\subsection{Electricity Sector}

Lithuania consumes about 8 TWh electricity in one year $(2002)^{61}$, while the total power plant production capacity in the country amounts to about $20 \mathrm{TWh}^{62}$. Like other energy sub sectors, the electricity network of Lithuania under the soviet regime was developed to become a constituent part of the Soviet Union joint energy system in the Northwest. Major power plants of the system included the power plant Lietuvos Elektrine, built in Elektrenai at the beginning of the seventies; Ignalina Nuclear Power Plant, put in operation in the eighties; and Kruonis Pumping Storage Plant, construction of which was started still under the Soviet regime. All these power plants were intended to meet the needs of a huge region, not just Lithuania. Lithuania's electricity grids are connected with those of Kaliningrad, Belarus and Latvia, which still make a part of the parallel operated unified energy system of Russia.

After a considerable decline of demand for electricity and the plunge of electricity export levels during the years of independence, the dominant position in the energy system of Lithuania was gradually taken over by Ignalina Nuclear Power Plant. Since 1992, Ignalina NPP has been producing over $80 \%$ of electricity consumed by Lithuanian users ${ }^{63}$. Such status of the nuclear power plant was determined first and foremost by the production costs which are considerably lower than those of other power plants of Lithuania (Lithuanian, Vilnius, Kaunas, Mažeikiai and Klaipeda Thermal Power Plants) ${ }^{64}$. Decommissioning of Ignalina Nuclear Power Plant (it is most likely to occur in 2004 (1st reactor) and 2009 (2nd reactor) as planned in the National Energy Strategy of Lithuania and the Negotiation Chapter 14 Energy $^{65}$ ), the largest electricity generation load will be put on the power plant Lietuvos Elektrine and other thermal power plants which use natural gas or fuel oil for production. The fuel oil is refined by Mažeikių Nafta oil refinery, or it could be imported; natural gas, as already mentioned, can only be imported from Russia. Incidentally, under negotiation chapter Environment Lithuania undertook to refrain from burning fuel oil

${ }^{61} \mathrm{AB}$ „Lietuvos energija“, AB “Lietuvos energija” akcininkai patvirtino 2002 metu veiklos rezultatus [AB Lietuvos Energija Approved 2002 Activity Results], http://www.lpc.1t/index.php?show_content id=291\&news_id=225, 10082003 (in Lithuanian).

${ }^{62}$ Miškinis (note $43 \overline{)}$, p. 9.

${ }^{63}$ Ibid, p. 10.

64 Ibid.

${ }^{65}$ ERK prie LRV, Derybos dèl narystès ES - derybinès pozicijos. Nr. 14 Energetika [Accession Negotiations. Negotiation Position No. 14 Energy], http://www.euro.lt/showitems.php?TopMenuID=2\&MenuItemID=9\&ItemID=440\&LangID=1, 15082003 (in Lithuanian). 
with sulphur contents above $1 \%$ until 2004, while fuel oil produced by Mažeikių Nafta oil refinery does not comply with such requirement ye $t^{66}$.

All of the above leads to a presumption, that still functioning Ignalina NPP to a certain extent reduces dependency of the Lithuanian energy sector upon Russia. Although the nuclear fuel suitable for Ignalina NPP is produced only in Russia, the supplies of such fuel are not of the uninterrupted nature, which undermines Russia's chances of destructing the activity of the Lithuanian energy sector by drastic means, such as cutting fuel supplies. After closure of Ignalina NPP, the bulk of electricity for the country will be produced by natural gas fuelled power plants, thus expanding Russia's influence on the energy sector in this country.

Of the major power plants (excluding Ignalina NPP):

1)The largest power plant Lietuvos Elektrinė uses natural gas, fuel oil and orimulsion, although only 1 block out of 8 is prepared to burn orimulsion, which is imported from Venezuela ${ }^{67}$; currently the Lithuanian Power Plant is working in a "stand-by" regime, and it will be the largest electricity producer after the closure of Ignalina Nuclear Power Plant.

2)Kaunas Thermal Power Plant may use natural gas and fuel oil, but since its acquisition by Gazprom lead consortia in 2003, it is most likely to use natural gas only.

3)Mažeikiai Thermal Power Plant may use natural gas and fuel oil;

4)Vilnius Thermal Power Plant currently may use natural gas and fuel oil; but in future it may switch part of its production on orimulsion ${ }^{68}$.

In some entities of the Lithuanian electricity sub sector Russia has a direct influence. In 2003, for instance, a consortium consisting of Gazprom, Dujotekana and Clement Power Venture purchased Kaunas Thermal Power Plant ${ }^{69}$. Russia has interests in other entities to be privatised: the Russian corporation JES Rossii, oil company Yukos and other Russian capital companies are among the candidates to acquire some profitable Lithuanian companies, including the distribution companies Rytu Skirstomieji Tinklai and Vakaru Skirstomieji Tinklai, Lietuvos Elektrinė and Kruonis Pumping Storage Plant, which has a potential of becoming a regulator of the Russian electricity supply system ${ }^{70}$.

${ }^{66}$ ERK prie LRV, LR derybine pozicija "Aplinka". (22 derybinis skyrius) [Negotiation Position of the Republic of Lithuania ,Environement', Negotiation Chapter No. 22], http://www.euro.lt/showitems.php?TopMenuID=2\&MenuItemID=9\&ItemID=448\&LangID=1, 15082003 (in Lithuanian). Currently the sulphur contents of fuel oil produced by $\mathrm{AB}$ Mažeikiu Nafta is $2.5 \%$. Modernisation of the refinery to able to produce the EU-standards compliant fuel oil would cost about 1 billion Litas. Lithuanian power plants will be able to burn fuel oil produced by Mažeikiu Nafta until 2008, but only in small quantities and alternating with natural gas. Liukaityte G., „Euroderybininkai nepadejjo "Mažeikių naftai" ['EU Negotiators Were of No Help to Mažeikiu Nafta'], Verslo žinios, 04022002 (in Lithuanian).

${ }^{67}$ Penki kontinentai online, Orimulsija ar dujos? [Orimulsion or Gas?], http://www.penki.lt/Article.asp?Lang=L\&ArticleID=5484, 25082003 (in Lithuanian).

${ }^{68}$ ELTA, "Vilniaus energija" rengia orimulsijos naudojimo studij ${ }^{1}$ [Vilniaus Energija Conducts Feasibility Study for Use of Orimulsion], 13112002 (in Lithuanian).

${ }^{69}$ BNS, Pasirašyta Kauno elektrinès pardavimo sutartis [The Treaty Signed for the Sale of Kaunas Power Plant], 31032003 (in Lithuanian).

${ }^{70}$ Damauskas Ž., „Rusijos energetikai braunasi ị Lietuvą“ [,Russian Energy Companies Invade Lithuania'], Lietuvos rytas, 19092002 (in Lithuanian); Markevičienè E., „Elektros tinklu privatizavimas gali užsitęsti“ [,Privatisation of Electricity Transmission Networks May be Protracted'], Lietuvos žinios, 16062003 (in Lithuanian). 
The Lithuanian market has become an exceptional focus of the Russian corporation RAO JES Rossii, a vertically and horizontally integrated natural monopoly in Russia's electricity sector run by “oligarch" A.Chubais, who is considered to be among the most influential persons in the internal policy domain. Since 2000, the daughter company of the corporation Inter RAO JES controls exports of the Lithuanian electric power to Belarus and Kaliningrad region. In March 2002, Lithuania undertook to continue co-operation with this company until the closure of Ignalina NPP. Thus, the business niches in the electricity market where Lithuania used to have certain advantages against Russia (e.g., Kaliningrad region has no other options of electricity supplies but import from Lithuania) have been handed over to the Russian company. Although dominance in the electricity export market (Inter RAO JES holds $84 \%$ of the Lithuanian electricity export market ${ }^{71}$ ) does not automatically mean that this company will take over control on other businesses in the Lithuanian electricity market, it must be admitted, that such business approach of Inter RAO JES enables the company to raise the capital for privatisation and build an relative advantage against other companies which might be willing to participate in the privatisation bid for the same entities, but, unlike Inter RAO JES, will have neither the experience of doing business in the Lithuanian market, nor formal and informal contacts.

Moreover, the company has already tested the same approach in other postsoviet countries Moldova, Armenia, Azerbaijan and others: first it put a feet between the doors of the electricity export market, and then participated in the privatisation of electricity transmission and power generating companies ${ }^{72}$. Inter RAO JES announced that it will seek expanding its activity into the markets of the Central and Eastern Europe, and Balkans in future ${ }^{73}$.

Back in 1997, Lithuania and Poland were discussing a possibility of joining their electricity networks ("power bridge"). This project could have enabled Lithuania to reduce its energy sector dependency on Russia in general, and dependency on exports into the Russian markets in particular; as well as to raise production efficiency in the energy market and to acquire a possibility to import excess electricity from Poland or the Western Europe, if it becomes necessary, e.g. after closure of Ignalina NPP. Unfortunately, the initial project feasibility studies were made at the time when the early closure plans of Ignalina NPP did not exist yet. The situation changed, the power bridge project was put into oblivion, and saw the daylight again only in 19992002, when a possibility to get the EU funding emerged. The total value of the project is about 1.4 billion Litas, period of implementation 6-7 years. Experts estimated, that the project is feasible provided $61 \%$ of its total value is covered by the grant from the EU funds ${ }^{74}$. Construction of the power bridge, however, could be delayed by the lack

${ }^{71}$ BNS, Pernai elektros energijos eksportas išaugo 63,4 proc. (papildytas) [Electricity Exports Increased by 63.4\% Last Year (Updated)], 03012003 (in Lithuanian).

${ }^{72}$ Наш ответ "Чемберлену"? [Our Response to ,Chamberlain'?], http://www.dnestr.ru/articles/ art_0502_01.htm, 17082003 (in Russian); Куда потекут финансовые потоки Армянской АЭС? [Where Proceeds from Armenia NPP Will Be Used?], http://www.diasp.ru/news/armeny/arc12003.shtml, 17082003 (in Russian), etc.

${ }^{73}$ „Анатолий Чубайс намерен объединить Россию и Европу“ [,Chubais Intends to Unify Russia and Europe'], Независимая газета, 28032002 (in Russian).

${ }^{74}$ Damauskas Ž., „Atgaivinama elektros tilto ị Vakarus ideja“ “, The Idea of Building Power Bridge to the West Has Been Revived'], Lietuvos rytas, 05102002 (in Lithuanian). 
of interest from the Polish side. Poland has an excessive power supply, and the country is interested in its own right to export the excessive electricity output to Slovakia and other countries in the Western Europe. Building of the power bridge would mean allowing competitors to enter its electricity export market.

However, even if the project is implemented, Lithuania can not get rid of the Russian influence in its energy market, because natural gas can be imported only from Russia, because Russian companies dominate in the electricity production market, and because of a price for electricity generated in the East, which is by far lower than the Lithuanian one (it might be a concern if Lithuania has to import electricity to compensate for its lack of the generating capacity). For instance, Belarus now buys electricity for its own needs from Ignalina NPP through a mediatorInter RAO JES, at the same time exporting the electricity generated by its own power plants through the same mediator to Poland - according to Belarus, "it is a better deal" $"$. No doubt, neither Russia nor Belarus are interested in Lithuania having a possibility to export electricity into the Western market directly, and the above example is just one illustration of the economic pressure that Inter RAO JES is capable of exerting upon exports of the Lithuanian electricity into the East European markets, meanwhile being interested in holding the most profitable entities of the Lithuanian energy sector. All of the above, the lack of interest from the Polish side in building the power bridge, as well as rather weak chances for Lithuania to get rid of the dependency upon natural gas supplies from Russia leads to a conclusion, that the dependency of the Lithuanian electricity generation sub sector upon Russia after closure of Ignalina NPP is most likely to increase.

\section{Conclusions}

The conclusion is that energy wise Lithuania does depend upon Russia. The chances of reducing such dependence are minimal, thus turning it into a real threat to the national security of this country. Analysis of the Lithuanian natural gas, oil and electricity sub-sectors highlights the following aspects of the energy dependence upon Russia:

1) dependence on imports of raw materials from Russia is of structural character; in the natural gas and electricity sector this type of dependence was determined either by a system of pipelines inherited from the Soviet era, or the technologies employed for construction of soviet energy objects (e.g., RBMK type reactors), which today presupposes complete dependence of the Lithuanian energy sector on raw material supplies from Russia;

2) by making resolute steps, the largest Russian energy companies themselves and (or) through their satellite companies have won control over the most important markets or businesses (e.g., control over the natural gas sector by Gazprom is materialized through its mediator, a Lithuanian company Dujotekana; Yukos dominates the oil supplies, refinery, export and even fuel retail sales markets; Inter RAO JES has entrenched in the electricity export market of Lithuania, etc.).

${ }^{75}$ Electricity and Heat Markes, http://www.rao-ees.ru/en/business/report2002/9_4.htm, 17082003. 
The first type of energy dependence (structural) threatens the national security by increasing vulnerability of the national economy and social stability, especially in cases of technical accidents (e.g., an accident in the pipeline used to carry gas or oil to Lithuania), or a conscious manipulation with such dependence (raw materials or their prices) for political purposes.

The second type of dependence - the consciously created and strengthened one - threatens the national security by giving the Russian companies, which dominate in a number of different energy sub sectors, a competitive advantage against other companies. Later Russian companies could use this advantage not only for privatisation of the major energy companies of Lithuania thus formalizing its hold over the energy sector, but also for influencing the fate of the energy projects aimed at increasing Lithuania's energy independence; in other words, Russia may, directly or indirectly, impede implementation of projects that may put Russia at a disadvantage (e.g., construction of the power bridge between Lithuania and Poland; merging the gas supply system with that of the EU, etc.). Awareness of the ever-increasing importance of economic leverages in the foreign policy of Russia, as well as of the developing co-operation of the regime and energy companies in Russia for the national security purposes, translates this threat into a realistic menace.

So far Lithuania has experienced the consequences of such increased co-operation only once, when the Russian company Lukoil imposed an economic blockade on the oil refinery Mažeikių Nafta during its privatisation. Although the primary purpose of such pressure upon Lithuania was of political character, a considerable damage was done to the national economy, too. In the history of Russia's foreign policy there have been other, though infrequent, instances of manipulation with energy dependence of other countries, and this fact increases the relevance of threat resulting from energy dependence to the national security even more.

The threat to national security is posed not only by direct or indirect attempts of Russia or Russian companies to anchor in the energy sector of Lithuania, but also by alternative projects that a have potential of reducing the competitive advantage of Lithuania against Russia. One example is construction of the terminal in Primorsk, which downgraded the importance of Būtingė Terminal for Russian energy companies.

The dominance of the nationalistic approach and geo-economic thinking in Russia's foreign policy is a certain warning signal to countries that depend upon Russia energy wise. In fact, the energy dependency related threat to national security cannot be mitigated even by hard or soft security guarantees that will be available for Lithuania once it becomes a fully-fledged member of NATO and the EU. 